\title{
Ethnobotany of Medicinal and Edible Plants of Tobelo Dalam Tribe in Aketajawe Lolobata National Park Area
}

\author{
Arham Yakub ${ }^{1}$, Amin Setyo Leksono², Jati Batoro \\ ${ }^{1}$ Master Program of Environmental Resources Management and Development, Brawijaya University \\ ${ }^{2}$ Biology Department, Faculty of Mathematics and Natural Sciences, Brawijaya University \\ Jl. Veteran, Malang, East Java, Indonesia
}

\begin{abstract}
This research aimed to find out local knowledge applied by the people of Tobelo Dalam tribe in the use of medicinal and edible plants. This research was carried out in Aketajawa Lolobata National Park at Aketajawe Block during April-June 2018. This research used a descriptive method through interviews and literature review. The selection of informants employed a snowball technique in which the main characteristics of the informants were the community leader, the traditional leader, and the community of the Tobelo Dalam Tribe. Data were analyzed using a qualitative analysis for data deepening on the ethnobotany study aspect based on the results of surveys and interviews obtained. The data were then analyzed using the Index of Cultural Significance (ICS) to determine the significance value of each plant species. The results showed that the number of plants used for treatment was 44 species dominated by those from the Malvaceae family such as achira or money tree (Pachira aquatica), cacao (Theobroma cacao), balacai or physic nut (Jatropha curcas L.) and dingo dingoto or climbing pandanus (Freycinetia sp). These plants are used for the treatment of mild wounds, allergic itching, postpartum and low stamina. Meanwhile, the number of edible plants often utilized by the people Tobelo Dalam Tribe was 7 species, covering Ipomoea batatas, Xanthosoma sp, Manihot utilisima, Oryza Sativa L., Metroxylon sagu, and Colocasia esculenta. These edible plants derived from 5 families dominated by Aracaceae (33\%), Euphorbiaceae (17\%), Convolvulaceae (17\%), and Palmae (16\%). The utilized parts of the edible plants were tubers and pith.
\end{abstract}

Keywords: Ethnobotany, Food, Medicine, Plant, Tobelo

\section{INTRODUCTION}

Tobelo Dalam Tribe still makes use of plants as medicine. The Aketajawe Lolobata National Park area, particularly the Aketajawe region, is where the people of Tobelo Dalam Tribe depend their lives on various germplasm sources. There are 149 species consisting of 100 agricultural germplasm sources (71 genera) used as foodstuffs and 49 species of medicinal plants [45 genera] used as medicinal ingredients [1].

The people of Tobelo Dalam Tribe have been knowledgable about the utilization and preservation of the diversity of natural resources, including the use of agricultural genetic resources. However, the knowledge system possessed by them so far has not been well. This is because of the lack of research on the existence of this tribe in relation to the utilization and preservation of biological resources, especially about plants [2].

The dependency of Tobelo Dalam Tribe in nature makes them have a Nomadic living system which is moving from place to place. To meet

Correspondence address:

Arham Yakub

Email : arhamria0204@gmail.com

Alamat : Master Program of Environmental Resources Management and Development their daily needs, the people of Tobelo Dalam Tribe search for food supplies such as tubers and fruits by moving from place to place. Whenever their food supplies get reduced, they will move to other areas to look for other staple food sources. This makes Halmahera ....., given that they were the first controlling and exploring the forest of Tobelo Dalam Tribe that was still primitive. At that time, they still did not know the farming or cultivation system. The livelihoods of the tribe were hunting, fishing, collecting forestry products, and collecting sago (Metroxylon sagu Rottb.) as a source of carbohydrates.

The documentation of the knowledge system of Tobelo Dalam Tribe will be very meaningful, especially to determine the diversity of genetic resources around the national park area, that are potentially developed further in the medicinal plant conservation program. The people of Tobelo Dalam tribe believe that plants basically need to be well treated and cared. With that way, plants will provide benefits and comfort to humans. The local knowledge of the people of Tobelo Dalam Tribe on how to seek medicinal ingredients and foodstuffs is a form of local wisdom as long as the utilization is in accordance with ecological rules. Based on ecological aspects, management of biological and environmental 
resources should benefit based on local wisdom so that the resources can be utilized continuously [3]. Management or utilization of resources by the community is indeed recognized as both positive and negative values. The positive value that can be taken by the local community from resources is the fulfilment of a number of needs, at least such as the traditional needs for foods and medicines [4].

Rural communities often fulfill their daily needs by utilizing flora both as foods and medicines. The use of herbs to cure diseases has been practiced since the early time of human history. In this regard, constant intimacy with the protection of vegetation has made primitive people get more knowledgeable about the usefulness of medicinal plants. The wisdombased use of plants by society is known as ethnobotany. Ethnobotany is a multidisciplinary knowledge that can be interpreted as an interaction between humans and plants [5]. Plants have been used in traditional medicine for thousands of years [6].

Based on the above background, this research was intended to find out local knowledge applied by the people of Tobelo Dalam Tribe in the use of medicinal and edible plants. This research was also a response to the lack of basic studies on the ethnobotany field, especially in Tobelo Dalam Tribe regarding the use of germplasm and its environmental management.

\section{RESEARCH METHODS}

This research was conducted in Aketajawe Lolobata National Park, SPTN (National Park Management Section) Region I Weda, Tayawi Resort, Koli Village, Tidore Island City from April to June 2018. This research is an ethnobotany study focusing on human interaction with the surrounding ecology. The data were collected using a descriptive interview method in which the informants were selected using a snowball technique [7]. The number of informants interviewed was 6 people who were the community leader, the traditional leader and the community of Tobelo Dalam Tribe. Data analysis used a qualitative analysis for data deepening on the ethnobotany study aspect based on the results of surveys and interviews obtained, then continued with an analysis using the Index of Cultural Significance (ICS) to determine the significance value of each plant species. According to Turner (1988), the score or value of ICS calculation shows the significance of the usefulness of each plant species for the community. This analysis can determine and find out the most important, quite important, less important, and even unknown species of ethnic life [8].

ICS $=\sum_{i=1}^{n}\left(q_{1} x i_{1} x e_{1}\right) n 1+\left(q_{2} x i_{2} x e_{2}\right) n i \ldots \ldots+\left(q_{n} x i_{n} x e_{n}\right) n i$

Description:

ICS: The total calculation of one to another utilization of a plant species

q : Quality value of a plant species ( $5=$ staple food; 4=secondary food/plants + primary material; $3=$ basic or raw material; $2=$ ritual, recreation and so on; and 1=more recognition)

i: Intensity value, reflecting the intensity of the utilization of useful plant species (5=very high intensity; 4=high intensity; $3=$ moderate intensity; 2=low intensity; $1=$ very low intensity)

e : Exclusive value ( $2=$ the most preferred, main choice and second to none; $1=$ there are still several species possible to be chosen; $0.5=$ secondary source or material)

The people of Tobelo Dalam Tribe settle in the Aketajawe Lolobata National Park area, especially in Tayawi region, Koli Village, Oba District, Tidore Island City. This group is known as Tayawi's Tobelo Dalam Tribe.

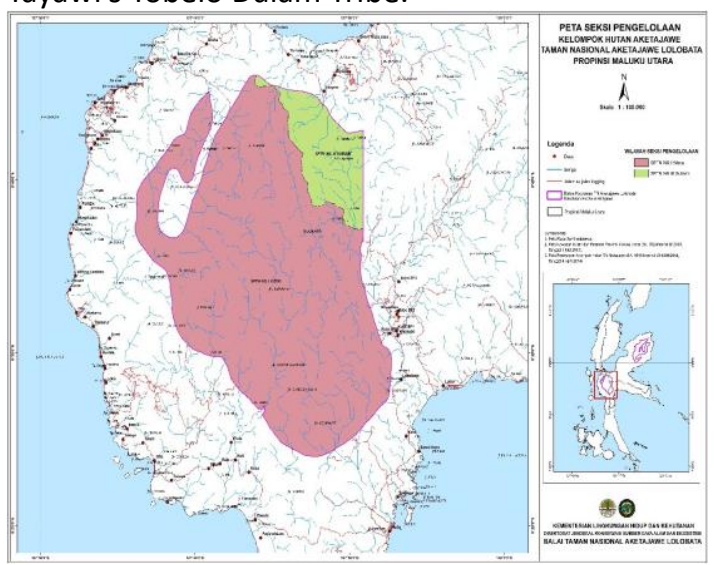

Figure 1. Location of Research on Tobelo Dalam Tribe

\section{RESULTS AND DISCUSSION}

Ethnobotany of Tobelo Dalam Tribe

Medicinal Plant Potential of Tobelo Dalam Tribe

The results of the research on Tobelo Dalam Tribe identified 44 species of forest plants containing medicinal properties and 7 species of edible plants usually consumed by the people of Tobelo Dalam Tribe. In general, the people of Tobelo Dalam Tribe often utilizes plant species of 
trees, lianas, herbs, shrubs, palms by making use of their leaves, roots, stems, and bark as ingredients for medicines. Of the 44 plant species identified, the most widely used medicinal plants based on the percentage of plant family can be seen in Figure 2 below.

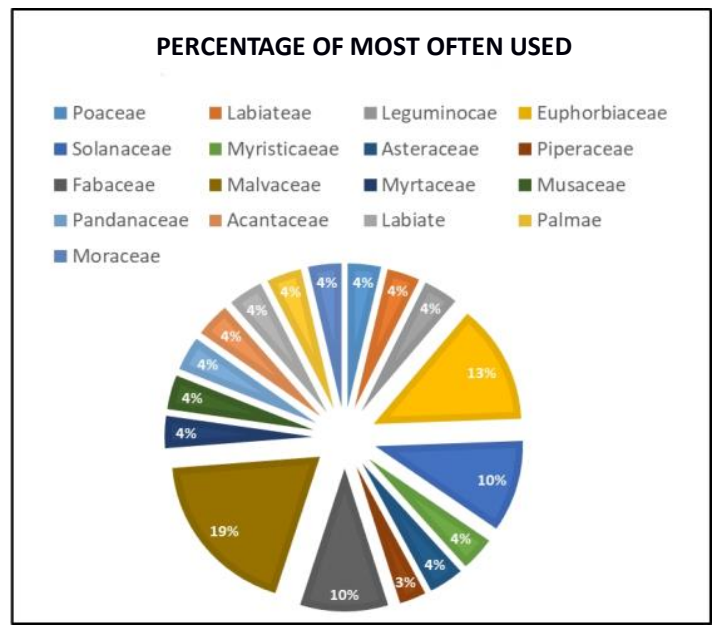

Figure 2. Percentage of Medicinal Plant Families

Based on Figure 2 above, the plants mostly used by the people of Tobelo Dalam Tribe as medicinal ingredients are those belonging to the families of Euphorbiaceae, Malvaceae, Leguminosae and Solanaceae. The plants from the Malvaceae family include achira or money tree plants (Pachira aquatica) and cacao plants (Theobroma cacao). The percentage of the use of the plants from the Malvaceae family was $19 \%$. Meanwhile, the plants from the Euphorbiaceae include kasbi (Manihot ulilisima) and balacai (Jatropha curcas L.). Many species of plants from the Euphorbiaceae family are used by Tobelo Dalam Tribe's people to make potions for traditional medicines, achieving a percentage of $13 \%$. Meanwhile, from all percentages of medicinal plants, there are several plants that can be utilized as food ingredients, medicinal ingredients, and firewoods, namely lamtoro or leadtree (Leucaena leucocephala L.). To make the potion from leadtree, we can take some white leadtree, boil them in a container for 20 minutes, let it for 10 minutes until being cool, and it is ready to consume. This potion can be used for treating or preventing someone from diabetes and reducing sugar levels. This medicine is only a supplement to the diet. Therefore, some people continue to consume this traditional medicine as an alternative in coping with the Diabetes Mellitus. One plant that can reduce blood sugar levels is Lamtoro gung (Leucaena leucocephala).
On the other side, the plants from the Fabaceae family include shrubs whose seeds contain a lot of calcium, phosphorus, and iron [9]. According to the calculation, the ICS value of lamtoro or leadtree (Leucaena leucocephala) was 102, meaning that this plant is useful for the people of Tobelo Dalam Tribe. However, there has been a phenomenon of degradation of local knowledge and utilization of medicinal plants experienced by all Indonesian ethnic groups [10]. Perception in the concept of sickness, health and its relation to the traditional use of medicinal plants is formed through appropriate socialization which has been hereditarily believed to be true [11].

\section{Medicinal Plants for Allergic Itching and Mild Wound}

The people of Tobelo Dalam Tribe have knowledge or tradition in healing the sickness or diseases of other people or even themselves. The medication is done in two ways, namely by reading a particular spell and then blowing it to the sick person or by reading it on a glass of water to be then given to and drunk by the sick person.

Some diseases that can be cured with herbs or traditional medicines based on the knowledge of Tobelo Dalam Tribe's people are those that can be directly treated by smearing, rubbing, dripping, or gargling with medicinal potions. The diseases are external diseases which only need external treatments. The treatment for external diseases does not need a lot of ingredient mixture but only a certain part of one plant species. Some of the diseases include canker sore, burns, and toothache.

Table 1. Medicinal Plants for Allergic Itching and Mild Wound

\begin{tabular}{|l|l|l|c|}
\hline No & Local Name & Scientific Name & $\begin{array}{c}\text { ICS } \\
\text { Value }\end{array}$ \\
\hline $\mathbf{1}$ & Binahong & Bassela Rubra L. & 100 \\
\hline $\mathbf{2}$ & Tali Sogili & $\begin{array}{l}\text { Homalium } \\
\text { Grandiflorum }\end{array}$ & 32 \\
\hline $\mathbf{3}$ & Sasoro & $\begin{array}{l}\text { Villebrunea } \\
\text { Rubescens BL. }\end{array}$ & 50 \\
\hline $\mathbf{4}$ & Sesen & $\begin{array}{l}\text { Semecarpus } \\
\text { Arborescens Kurz. }\end{array}$ & 50 \\
\hline $\mathbf{5}$ & Dingo Dingoto & Freycinetia Sp. & 70 \\
\hline
\end{tabular}

Binahong or Malabar spinach (Bassela rubra L.) is a medicinal plant which has a very good effect for burn infection. This plant species is used by Tobelo Dalam Tribe's people to cure boil infection, headaches, allergic itching, body odor, 
and eye mild irritation. The plant species as shown in Table 1 can also be used for severe disease treatment. According to the information obtained from the people of Tobelon Dalam Tribe, binahong can be used to treat severe infections or wounds due to being hit by an arrow or being cut. To make the binahong potion, we should take some young binahong leaves and pound them finely. This potion can be smeared on injured body parts. Besides, the pounded binahong leaves can also be added with a glass of water to be then filtered and drunk for healing internal diseases, intestinal inflammation, ulcers, low immune system, and stomachache. Bioactive substances contained in binahong plants can help the healing process of degenerative diseases such as kidney damage, diabetes, and others. Besides, the secondary metabolite content of binahong as an antioxidant and antimicrobial/ antibiotic is very useful as a raw material for traditional medicines [12]. Binahong plants can be utilized as ingredients for food, medicines, and waterresistance. Consuming binahong is very useful for the health of Tobelo Dalam Tribe's people. According to the calculation results, the ICS value of binahong plants was 100 .

Furthermore, the people of Tobelo Dalam Tribe also utilize dingo dingoto leaves (Freycinetia $\mathrm{sp})$ as medicines for wounds and headache. Dingo dingoto leaves can be utilized by taking the leaf shoots and then pounding them finely. This medicine can be attached to the head in the morning and evening. It can also be smeared on the wound. Similar to other studies of medicinal plants in a community, leaves are generally the widely-used part of plants in herbal medicines. This is in accordance with Hidayat's study [13] suggesting that leaves are part of plants that is mostly used by the community of Dukuh indigenous village, West Java, equal to $50 \%$ of the 150 species of 37 medicinal plants used by the community.

\section{Medicinal Plants for Stamina Enhancement}

The people of Tobelo Dalam Tribe surrounding Aketajawe Lolobata National Park have local wisdom to increase their stamina so as to remain stable and healthy while working and undergoing daily activities. Potions for femininity disorders, postpartum care, and increased fertility in women are made of plants commonly found in the forest. Plants utilized for stamina enhancement and postpartum care can be seen in Table 2 below, along with its usefulness and benefits.
Table 2. Medicinal Plants for Stamina Enhancement and Postpartum Care

\begin{tabular}{|c|l|l|c|}
\hline No & \multicolumn{1}{|c|}{ Local Name } & \multicolumn{1}{|c|}{ Scientific Name } & $\begin{array}{c}\text { ICS } \\
\text { Value }\end{array}$ \\
\hline $\mathbf{1}$ & Rattan & Calamus Sp. & 100 \\
\hline $\mathbf{2}$ & Areca palm & Areca Catechu L. & 100 \\
\hline $\mathbf{3}$ & Piper Betle & Piper Sp. & 50 \\
\hline $\mathbf{4}$ & Butterfly Leaves & $\begin{array}{l}\text { Bauhinia Elongata } \\
\text { Korth. }\end{array}$ & 50 \\
\hline $\mathbf{5}$ & Kamahi & Weinmannia Sp. & 50 \\
\hline
\end{tabular}

The people of Tobelo Dalam Tribe still apply highly traditional and natural treatments. The table above explains the medicinal plants often used by the people to enhance their stamina and recover postpartum health. The medicinal plants used for increasing stamina include rattan (Calamus sp.) and forest areca (Areca catechu L.). The two plants complement each other in the making of stamina enhancing potion. The ingredients used to make the potion are the base of rattan (Calamus sp.) stems mixed with the roots of forest areca (Areca catechu L.) and added with two cups of water. These ingredients are then boiled in bamboo and let for 10 to 20 minutes until being cool. The potion is better drunk in the afternoon. Additionally, rattan plants (Calamus sp.) can also be used for several needs, such as foodstuff, medicines, and firewood. Therefore, the plants are significantly helpful for Tabelo Dalam Tribe's people. The use values of rattan (Calamus sp.) and forest areca (Areca catechu L.). were similarly 100 . On the other side, Piper betel plants (Piper sp.) can cure postpartum pain. To make the potion, we can take 10-15 piper betel leaves, boil them with sufficient water, and let it for 20 minutes until being cool. This potion is better drunk in the morning.

Clinically, the extract of meniran has been proven to be immunostimulant or able to stimulate a person's immune system in order to be invulnerable against diseases. Meniran also contains several chemical ingredients including flavonoids which can stimulate the human body's immune system to work better [14].

Meanwhile, butterfly leaves (Bauhinia elongate Korth) has the potential to increase fertility in women. To make the potion from butterfly leaves, we can take some butterfly leaves, anthill, Cinnamomum culilawan (kayu lawang) bark, and mongarepe roots, boil them together, and let it until being warm before 
drunk. The potion is better to consume every day. Butterfly leaves contain flavonoids, saponins, tannins, terpenoids, alkaloids, and polyphenols which are very beneficial as medicines such as for fever, constipation, cough, and antibacterial. Besides, butterfly leaf extract contains antibacterial substances so that it is safe to use as external medicines.

\section{Commodity and Edible plants}

The topographical conditions of Tobelo Dalam Tribe within the lower slopes of Aketajawe Lolobata National Park are very excellent for the growth of natural plants which are often utilized as medicinal ingredients and foodstuff for daily life. The commodity and edible plants usually cultivated and utilized by the people are shown in Table 3 below.

Table 3. Edible Plant Species in Tobelo Dalam Tribe

\begin{tabular}{|l|l|l|c|}
\hline No & \multicolumn{1}{|c|}{ Local Name } & \multicolumn{1}{c|}{ Family } & ICS Value \\
\hline $\mathbf{2}$ & Batata & Convolvulaceae & 50 \\
\hline $\mathbf{3}$ & Bete & Aracaceae & 50 \\
\hline $\mathbf{4}$ & Goyoba/Sibii/kasbi & Euphorbiaceae & 40 \\
\hline $\mathbf{5}$ & Pine (rice) & Gramineae & 50 \\
\hline $\mathbf{6}$ & Halime & Palmae & 40 \\
\hline $\mathbf{7}$ & Kaladi & Aracaceae & 50 \\
\hline
\end{tabular}

PERCENTAGE OF MOST OFTEN USED
EDIBLE PLANT FAMILIES
$\square$ Convolvulaceae $\approx$ Aracaceae $\quad$ Euphorbiaceae
$\square$ Gramineae $\quad$ Palmae

Figure 3. Percentage of Edible Plant Family

Based on Figure 3 above, there are 7 species of edible plants often used by the people of Tobelo Dalam Tribe, namely batata or sweet potato (Ipomoea batatas), bete or tannia (Xanthosoma sp.), pine or rice (Oryza Sativa L.), halime or sago palm (Metroxylon sagu), and kaladi or taro (Colocasia esculenta). According to the percentage, the most popular plant family was Aracaceae (33\%) in which the most preferred plant species belonging to this family was bete or tannia (Xanthosoma sp.). The other popular edible plant families to meet the needs of food of the tribe were Convolvulaceae (16\%), Euphorbiaceae (17\%), Gramineae (17\%) and Palmae (17\%). This is because the cultivation of these plants is not too difficult and does not require special land. tannia can be planted between other plants (alternate plants) or in the house yard. According to Permana [15], almost every community has unique local wisdom as a strategy for adaptation to the environment. He added that food derived from high-level plants can be obtained from forest products in the form of fruits, leaves, and seeds [15].

The people of Kopen Dukuh still use spice plants for various purposes, such as food seasonings and medicines for maintaining health or stamina. The introduction of spice plant species and their utilization is derived from parents and previous ancestors both orally and practically. The model of information transfer between generations can still be seen in the culture of rural communities in Banyuwangi, indicating that traditional aspects are still maintained [16].

\section{CONCLUSION}

Based on the results and discussion explained above, some points that can be concluded from this research are as follows:

1. The people of Tobelo Dalam Tribe have a very close relationship with the environment where they live by making an adaptation to the environment in the form of knowledge about the use of plants and its sustainability to meet their life needs.

2. There are 44 plant species in the Tobelo Dalam Tribe area that can be utilized as medicines, most of which belong to the families of Euphorbiaceae (13\%), Malvaceae (19\%), Leguminosae (10\%) and Solanaceae (10\%). The plants included in the Malvaceae family are achira or money tree plants (Pachira aquatica) and cacao (Theobroma cacao). The plants from the Malvaceae family are the most often used by the people of Tobelo Dalam Tribe in medicines. The plants from the Euphorbiaceae family include goyoba/sibii/kasbi or cassava (Manihot ulilisima) and balacai or physic nut (Jatropha curcas L.). From the Leguminosae family, the plant often used by the people of the tribe is lamtoro or leadtree (Leucaena leucocephala). In the Solanaceae family, ceplukan or Cutleaf Ground Cherry (Physalis angulata L.) is the most often used plant in Tobelo Dalam Tribe. 
3. There are 7 edible plant species often utilized by the people of Tobelo Dalam Tribe, dominated by tannia (talas) and taro (kaladi) from the Aracaceae family (33\%). The other plant families often processed by the people for daily food needs include Euphorbiaceae (17\%), Gramineae (17\%), Palmae (17\%), and Convolvulaceae (16\%).

\section{SUGGESTION}

1. The people of Tobelo Dalam Tribe should be informed and given knowledge about plants that have high values and efficacy to be utilized, especially those containing conservation values that need to be maintained.

2. Aketajawe Lolobata National Park Agency together with the local government should carry out socialization and training on the cultivation of several potential plant species for the people of Tobelo Dalam Tribe surrounding the forest area.

\section{REFERENCE}

[1]. Karim, K.A., Thohari, M.\&Sumardjo. (2006). Pemanfaatan keanekaragaman genetik tumbuhan oleh masyarakat Togutil disekitar Taman Nasional Aketajawe Lolobata. Media Konservasi, XI(3), 1-12.

[2]. Balai Taman Nasional Aketajawe Lolobata. 2009. Buku Statistik 2009. Balai Taman Nasional Aketajawe Lolobata. Ternate

[3]. Awang. 2002. Etnologi Manusia Di Hutan Rakyat. Sinergi Press. Yogyakarta 2-36.

[4]. Halmanto R, 2010. Etnoekologi. Bandar Lampung: Universitas Lampung.

[5]. Virman, Piyush Paul, V. Kumar, Kuldeep Yagik, Vinod Gupta. 2013, Biodiversity of Ethnomedicinal Plants Used by Traditional Healers In Remote Villages of Datiadistrict of Bundelkhand Region, India. The Journal of Ethnobiology And Treditional Medicine. Phaton 118, 269-278.

[6]. Savithramma, P Yugandhar, M. Linga Rao. 2013. Documentation of Ethnobotanical Knowledge of Ethnic Groups From Kurnool District, Andhra Pradesh, India. The Journal of Ethnobiology and Tredition Medicine. Photon 118, 295-305.

[7]. Singarimbun, M dan Effendi. 2010. Metode Penelitian Survei. LP3S. Yogyakarta, 12-17.

[8]. Turner, N.J. (1988). "The Importance of a Rose": Evaluating the Cultural Significance of Plants in Thompson and Lillooet Interior
Salish. Royal British Columbia Museum, British. 274p.

[9]. Studiawan dan Santosa. 2005. Uji Aktivitas Penurun Kadar Glukosa Darah Ekstrak Daun Eugenia polyantha pada Mencit yang Diinduksi Aloksan. Jurnal Media Kedokteran Hewan Vol. 21, No. 2, Mei 2005. Bagian Ilmu Bahan Alam, Fakultas Farmasi , Universitas Airlangga Surabaya

[10]. Purwanto, Y., Laumonir \& M. Malaka. 2004 Antropologi Dan Etnobotani Mayarakat Yamdana Di Kepulauan Tanimbar. Tanimbar LUP/Bapeda, Jakarta: xiv +193 hlm

[11]. Rahayu M, Susiarti S, Purwanto Y. 2006. Kajian Pemanfaatan Tumbuhan Hutan Non Kayu oleh Masyarakat Lokal di Kawasan Konservasi PT Wira Karya Sakti Sungai Tapa-Jambi. Biodiversitas 8 (1) :73-78.

[12]. Manitto P. 1992. Biosintesis Produk Alami. Penerjemah Koen Sumardiyah. Semarang: IKIP Press. Hal. 70-79.

[13]. Hidayat S. 2010 Etnobotani Masyarakat Kampung Adat Dukuh Di Garut, Jawa Barat (Skripsi). Bogor: Fakulta Kehutanan. Institut Pertanian Bogor.

[14]. Kardinan, A \& Kusuma, F.R. (2004). Meniran penambah daya tahan tubuh alami. Jakarta: Agromedia.

[15]. Permana, E., Nasution, I.P Dan Gunawijaya, J. 2011. Kearifan Lokal Tentang Mitigasi Bencana Pada Masyarakat Baduy. Jurnal Makara (15) 1, 67-68.

[16]. Hakim, L, J. Batoro, K. Sukenti. 2015. Etnobotani Rempah-Rempah di Dusun Kopen Dukuh, Kabupaten Banyuwangi. Indonesian Journal of Environment and Sustainable Development. Vol. 6 no. 2 . 133-135. 